\title{
Consensus guidelines for the treatment of infectious endocarditis with outpatient parenteral antibiotic therapy
}

\author{
Shurjeel H Choudhri MD FRCPC and The Endocarditis Care Plan Working Group*
}

\begin{abstract}
SH Choudhri and The Endocarditis Care Plan Working Group. Consensus guidelines for the treatment of infectious endocarditis with outpatient parenteral antibiotic therapy. Can J Infect Dis 2000;11(Suppl D):4D-10D.

The development of single, daily dose antibiotic regimens and the availability of computerized ambulatory infusion pumps have made it possible for most patients with infectious endocarditis (IE) to complete their treatment in an outpatient setting. This review summarizes the current literature on the classification, diagnosis, clinical and laboratory manifestations, and inpatient and outpatient management of IE. An algorithmic approach to the diagnosis and management of IE is proposed. Most patients with IE who are clinically stable and do not require a surgical procedure can be managed using outpatient parenteral antibiotic therapy. Results from several small studies suggest that outpatient parenteral antibiotic therapy for IE is safe, efficacious and economical.
\end{abstract}

Key Words: Consensus guidelines; Endocarditis; Outpatient treatment

\section{Directives consensuelles pour le traitement de l'endocardite infectieuse par antibiothérapie parentérale ambulatoire}

RÉSUMÉ : La mise au point de schémas d'antibiothérapies quotidiennes simples et l'accessibilité à des pompes à perfusion informatisées ambulatoires permettent à la plupart des patients qui souffrent d'une endocardite infectieuse de terminer leur traitement sans être hospitalisés. Le présent article résume la littérature actuelle sur la classification, le diagnostic, les manifestations cliniques et les résultats d'analyses de laboratoire, de même que le traitement de l'endocardite infectieuse avec ou sans hospitalisation. On propose ici un algorithme pour le diagnostic et le traitement de l'endocardite infectieuse. La plupart des patients qui en sont atteints, qui sont cliniquement stables et ne requièrent pas d'intervention chirurgicale peuvent être traités sans hospitalisation par antibiothérapie parentérale. Les résultats de plusieurs petites études suggèrent que l'antibiothérapie parentérale en externe est sûre, efficace et économique dans les cas d'endocardite infectieuse.

I nfectious endocarditis (IE) refers to an infection of the endocardium resulting in the development of vegetations on a heart valve or, less commonly, on the mural endocardium. Despite the availability of curative therapy, it continues to be associated with high morbidity and mortality. While the overall incidence of IE has remained unchanged over the past 50 years, an increased incidence of IE has been seen in the elderly, those with prosthetic valves and injection drug users (IDUs) (1-4).

The last quarter century has seen important advances in the diagnosis and management of IE. The availability of transesophageal echocardiography, new diagnostic criteria such as the Duke's criteria and the development of short course, once daily, oral, outpatient treatment regimens have revolutionized the diagnosis and treatment of IE (1). Outpatient parenteral antibiotic therapy (OPAT) programs allow most patients with uncomplicated IE to complete their treatment course in the community, thus minimizing the length of their hospital stay. The objective of this review is to summarize the current knowledge of IE with special attention to its treatment in the community by OPAT programs.

*Dr Gerald A Evans, Kingston General Hospital, Kingston, Ontario; Ms Natalie Thickson, Ms Maria Lazaruk, Ms Leslie Dryburgh, Ms Theresa Imlah, Ms Lisa Houtkooper, Mr Luke McKenzie, Dr Karen A Doucette and Ms Glenna Germaine, St Boniface General Hospital, Winnipeg, Manitoba Correspondence and reprints: Dr Shurjeel H Choudhri, Medical Research, Anti-infectives/Biologics, Bayer Corporation, 400 Morgan Lane, West Haven, Connecticut 06518 USA. Telephone 203-812-2186, fax 800-520-2807, e-mail schoudhri@snet.net 


\section{COPYICHT PULSUS GROU CLASSIFICATION AND ETIOLOGY}

IE can be divided into three categories: native valve endocarditis, prosthetic valve endocarditis (PVE) and endocarditis in IDUs. Native valve IE is most commonly caused by Streptococcus species, Staphylococcus aureus and Enterococcus species (5). Most patients (60\% to $80 \%$ ) with IE have an identifiable, predisposing cardiac lesion such as a bicuspid aortic valve, a mitral valve prolapse or rheumatic valvular disease $(6,7)$. Endocarditis can also be classified as acute or subacute. Acute IE is caused by virulent organisms such as $S$ aureus, which can infect normal heart valves and are rapidly fatal if not treated promptly. Subacute IE results from infection of structurally abnormal valves by less virulent organisms such as viridans streptococci.

PVE can be further subclassified as early or late. Early infection occurs within two months of valve replacement and is usually due to contamination during surgery. Staphylococcus epidermidis and $S$ aureus are the most common organisms identified in this situation $(8,9)$. Late PVE occurs more than two months after valve replacement, and is usually due to transient bacteremia with subsequent seeding of the valve, although some cases may still result from organisms acquired during the surgery. Streptococci are the most commonly isolated organisms in late PVE, followed by staphylococci and, much less commonly, Gram-negative rods and fungi (9-11).

Infective endocarditis in IDUs usually involves the tricuspid valve, although left-sided endocarditis may also occur in IDUs with pre-existing valve abnormalities. $S$ aureus is the most common organism isolated, followed by enterococci, streptococci and Gram-negative rods such as Pseudomonas species and Serratia species (12).

\section{CLINICAL MANIFESTATIONS}

Most patients with IE present with fever along with nonspecific symptoms such as chills, night sweats, anorexia and fatigue $(11,13)$. The fever is usually low grade and remittent in cases of subacute IE, with temperatures rarely exceeding $39^{\circ} \mathrm{C}$; however, temperatures may be higher in cases associated with virulent organisms such as $S$ aureus (14). Musculoskeletal complaints are present in approximately $40 \%$ of patients, with arthralgias, myalgias and back pain being the most common. Most patients (90\%) with IE have a murmur, although a new or changing murmur is only observed in $36 \%$ to $53 \%$ (13). Cutaneous manifestations such as petechiae and splinter hemorrhages may be observed in up to $50 \%$ of patients. Splenomegaly is now a relatively uncommon finding, being observed in less than $20 \%$ of patients $(1,6)$.

Many patients may initially present with a complication of IE. Congestive heart failure is the most common complication and is observed in $38 \%$ to $60 \%$ of IE patients (14). Embolic phenomena are the second most frequent complication and may occur at any time during the course of the illness (15). Occasionally, the patient may present with an acute cerebrovascular accident. Patients with right-sided IE may present with multiple, rounded pulmonary infiltrates with or without cavitation due to infected pulmonary emboli (1). Mycotic aneurysms are the third most common complication, occurring in
$5 \%$ to $10 \%$ ol cases. These often involve the central nervous system and may be clinically silent until they rupture (16). Other complications include the development of renal dysfunction due to embolization of the kidneys or the development of immune-mediated glomerulonephritis (1).

\section{LABORATORY FINDINGS}

Common laboratory findings in IE include normochromic normocytic anemia ( $70 \%$ to $90 \%$ of cases), leukocytosis ( $20 \%$ to $30 \%$ ), an elevated erythrocyte sedimentation rate (greater than $90 \%$ ), elevated C-reactive protein levels, positive rheumatoid factor $(40 \%$ to $50 \%)$, proteinuria $(50 \%$ to $65 \%$ ) and hematuria (30\% to $50 \%$ ) (17). Most patients with IE (78\% to $95 \%)$ have a positive blood culture. Prior antibiotic therapy is the most common reason for negative blood cultures in a patient with IE (5).

\section{DIAGNOSIS}

An early diagnosis requires a high degree of clinical suspicion, because patients with IE may present with nonspecific symptoms. Blood cultures should be obtained from all individuals suspected of having IE, and all should undergo echocardiography. Transesophageal echocardiography can detect both vegetations and perivalvular infections with a sensitivity of $80 \%$ to $90 \%$, and is superior to transthoracic echocardiography for diagnosing IE $(18,19)$. Serial blood cultures should be obtained if the original blood culture is negative. Once an organism has been isolated and identified, the minimum inhibitory concentration (MIC) and minimum bactericidal concentration should be determined to guide further antimicrobial therapy.

The Duke's criteria (19) use clinical, microbiological and echocardiographic findings to establish a diagnosis of definite or possible IE, and have largely supplanted previously described criteria for IE (20). Two major, or one major plus three minor, or five minor criteria establish a definitive clinical diagnosis of IE (Table 1).

\section{THERAPY OF IE}

Ideally, all patients with a suspected diagnosis of IE should be admitted for diagnostic workup and monitoring. Empirical therapy with a bactericidal antibiotic regimen should be initiated in all patients with acute IE while awaiting the culture results. An early surgical consultation should be obtained in any patient developing a complication of IE and in all patients with PVE (14). Indications for surgical therapy for IE are outlined in Table 2, while Tables 3 to 5 summarize the empirical antibiotic regimens for the different types of IE. Therapy for subacute endocarditis can usually be delayed for 24 to $48 \mathrm{~h}$, until the culture results become available. Definitive therapy is based on the culture results, and is outlined in Tables 3 to 6 .

\section{DEFINITIVE THERAPY OF IE}

The recommended treatment regimens for native valve, prosthetic valve and right-sided IE are listed in Tables 3, 4 and 5 , respectively. Table 6 outlines the treatment choices available for managing IE in penicillin-allergic patients.

Native valve endocarditis - Viridans streptococci: Specific therapy of streptococcal infections is based on their suscepti- 
TABLE 1 COPYRIGHT PULSUS GROUP ING. - DO NOT COPY

\section{Duke's diagnostic criteria for infectious endocarditis (IE)}

Definite IE

Pathological criteria

- Microorganisms: demonstrated by culture or histology in a vegetation, a vegetation that has embolized or an intracardiac abscess or

- Pathological lesions, such as: vegetations or intracardiac abscess present, confirmed by histology showing active endocarditis Clinical criteria

To establish a definitive diagnosis of IE, a patient must have two major, one major and three minor, or five minor criteria Major criteria

- Isolation of viridans streptococci, Streptococcus bovis, HACEK group organisms, or (in the absence of a primary focus) communityacquired Staphylococcus aureus or enterococcus from two separate blood cultures; or isolation of a microorganism consistent with endocarditis in blood cultures $12 \mathrm{~h}$ or more apart, or all of three, or most of four or more, blood cultures, with the first and last cultures performed at least $1 \mathrm{~h}$ apart

- Evidence of endocardial involvement on echocardiography: oscillating intracardiac mass or abscess, new partial dehiscence of prosthetic valve or new valvular regurgitation

Minor criteria

- Predisposing lesion or intravenous drug use

- Fever $\geq 38^{\circ} \mathrm{C}$

- Vascular phenomena: major arterial emboli, septic pulmonary infarcts, mycotic aneurysm, intracranial hemorrhage, conjunctival hemorrhages or Janeway lesions

- Immunological phenomena: glomerulonephritis, Osler's nodes, Roth's spots or positive rheumatoid factor

- Microbiological evidence: positive blood cultures not meeting the major criteria (excluding single cultures positive for organisms that usually do not cause endocarditis) or serological evidence of active infection with an organism that causes endocarditis

- Echocardiogram consistent with endocarditis but that does not meet the major criteria

Possible IE

Findings consistent with IE that fall short of 'definite' but are not 'rejected'

Rejected IE

- Firm alternate diagnosis for manifestations of IE

or

- Resolution of manifestations of IE with antibiotic therapy for four days or less

or

- No pathological evidence of IE at surgery or autopsy after antibiotic therapy of four days or less

HACEK group organisms Haemophilus parainfluenzae, Haemophilus aphrophilus, Actinobacillus actinomycetemcomitans, Cardiobacterium hominis, Eikenella corrodens, Kingella kingae. Information taken from reference 19

\section{TABLE 2}

\section{Indications for surgical therapy}

Absolute

- Refractory congestive heart failure

- More than one systemic embolic complication

- Uncontrolled infection (positive blood cultures after three to five days of appropriate therapy)

- Valve dysfunction as demonstrated by fluoroscopy

- Ineffective antimicrobial therapy (eg, fungal endocarditis)

- Resection of mycotic aneurysms

- Most cases of prosthetic valve endocarditis

- Local suppurative complications (eg, annular or myocardial abscess, valve rupture)

- Fungal endocarditis

Relative

- Moderate congestive heart failure

- Progressive renal failure (immune complex disease, embolization)

- Large vegetation

Information taken from references 6 and 13

bility to penicillin $\mathrm{G}$ (21). Those with MICs of $0.1 \mu \mathrm{g} / \mathrm{mL}$ or less can be managed with a four-week course of penicillin or ceftriaxone, or a two-week course of penicillin or ceftriaxone plus gentamicin (21-23). A two-week course of ceftriaxone followed by two weeks of oral amoxicillin has also been shown to be effective (23). Streptococci with penicillin G MICs between 0.1 and $0.5 \mu \mathrm{g} / \mathrm{mL}$ require a regimen of high dose penicillin $\mathrm{G}$ for four weeks, plus gentamicin for the first two weeks (21). This regimen can also be used for nutrient-deficient streptococci. Penicillin may not be bactericidal against streptococci with penicillin G MICs greater than $0.5 \mu \mathrm{g} / \mathrm{mL}$. These organisms should be treated with the same regimens as enterococci (21).

Vancomycin can be substituted for penicillin in patients with a history of penicillin allergy. Ceftriaxone is also an alternative in this situation because of the minimal cross-reactivity between penicillin and third-generation cephalosporins.

Enterococci: Penicillin, ampicillin and vancomycin are not bactericidal against enterococci, and the addition of an aminoglycoside such as streptomycin or gentamicin is required to produce a synergistic bactericidal effect. Synergy is only seen if the MIC is less than $2000 \mu \mathrm{g} / \mathrm{mL}$ or less than $500 \mu \mathrm{g} / \mathrm{mL}$ to streptomycin and gentamicin, respectively (21). The usual treatment course is for six weeks. No satisfactory regimens are available to treat enterococci that have high level resistance to aminoglycosides.

Staphylococci: A four- to six-week course of intravenous cloxacillin remains the treatment of choice for methicillinsusceptible $S$ aureus and $S$ epidermidis (21). Cefazolin may be substituted for cloxacillin in selected patients with a penicillin allergy (21). The addition of gentamicin for the first three to five days of therapy produces a more rapid clearing of the bacteremia but has not been shown to reduce the complication rate or increase the cure rates (24). Current evidence suggests that vancomycin may be less effective than cloxacillin in treating IE and s- 
TABLE 3

COPYRIGHT PULSUS GROUP INC, - DO NOT COPY

Recommended antibiotic regimens for the treatment of native valve infectious endocarditis

\begin{tabular}{|c|c|c|c|}
\hline Organism & Regimens & Comments & References \\
\hline Empirical therapy & $\begin{array}{l}\text { - Ampicillin } 3 \mathrm{~g} \text { IV every } 6 \mathrm{~h} \text { plus cloxacillin } 2 \mathrm{~g} \text { IV every } 4 \mathrm{~h} \\
\text { plus gentamicin } 1 \mathrm{mg} / \mathrm{kg} \text { IV every } 8 \mathrm{~h}\end{array}$ & & 30 \\
\hline $\begin{array}{l}\text { Nutrient-deficient } \\
\text { streptococci }\end{array}$ & $\begin{array}{l}\text { - Penicillin G } 4 \mathrm{mU} \text { IV every } 4 \mathrm{~h} \text { for four weeks plus } \\
\text { gentamicin } 1 \mathrm{mg} / \mathrm{kg} / \text { dose IV every } 8 \mathrm{~h} \text { for two weeks }\end{array}$ & & $6,21,30$ \\
\hline $\begin{array}{l}\text { Staphylococcus } \\
\quad \text { aureus } \\
\text { (methicillin } \\
\text { sensitive) }\end{array}$ & $\begin{array}{l}\text { - Cloxacillin } 2 \text { g IV every } 4 \mathrm{~h} \text { for six weeks } \\
\text { - Cloxacillin } 2 \text { g IV every } 4 \mathrm{~h} \text { for six weeks plus gentamicin } \\
1 \mathrm{mg} / \mathrm{kg} / \text { dose IV for five days } \\
\text { - Cefazolin } 2 \text { g IV every } 8 \mathrm{~h} \text { for six weeks plus gentamicin } \\
1 \mathrm{mg} / \mathrm{kg} / \text { dose IV every } 8 \mathrm{~h} \text { for six weeks }\end{array}$ & & $6,21,30$ \\
\hline Enterococci & $\begin{array}{l}\text { - Ampicillin } 3 \mathrm{~g} \text { IV every } 4 \mathrm{~h} \text { for four to six weeks plus } \\
\text { gentamicin } 1 \mathrm{mg} / \mathrm{kg} / \text { dose IV every } 8 \mathrm{~h} \text { for four to six weeks } \\
\text { - Penicillin } \mathrm{G} 5 \mathrm{mU} \text { IV every } 4 \mathrm{~h} \text { for four to six weeks plus } \\
\text { gentamicin } 1 \mathrm{mg} / \mathrm{kg} / \text { dose IV every } 8 \mathrm{~h} \text { for four to six weeks }\end{array}$ & $\begin{array}{l}\text { Treatment regimen may not be 'cidal' if high } \\
\text { level resistance to aminoglycosides is present }\end{array}$ & $1,6,21,30$ \\
\hline HACEK group & $\begin{array}{l}\text { - Ampicillin } 12 \text { g every } 24 \mathrm{~h} \text {, continuously or in six divided doses, } \\
\text { plus gentamicin } 1 \mathrm{mg} / \mathrm{kg} / \text { dose IV every } 8 \mathrm{~h} \text { for four weeks }\end{array}$ & $\begin{array}{l}\text { Although ceftriaxone is active against most } \\
\text { HACEK organisms, treatment should be based } \\
\text { on the susceptibility profile of the isolate } \\
\text { Use only if organism is a nonbeta-lactamase } \\
\text { producer }\end{array}$ & $6,21,30$ \\
\hline
\end{tabular}

HACEK group organisms Haemophilus parainfluenzae, Haemophilus aphrophilus, Actinobacillus actinomycetemcomitans, Cardiobacterium hominis, Eikenella corrodens, Kingella kingae. IV Intravenous

\section{TABLE 4}

Recommended antibiotic regimens for the treatment of prosthetic valve infectious endocarditis

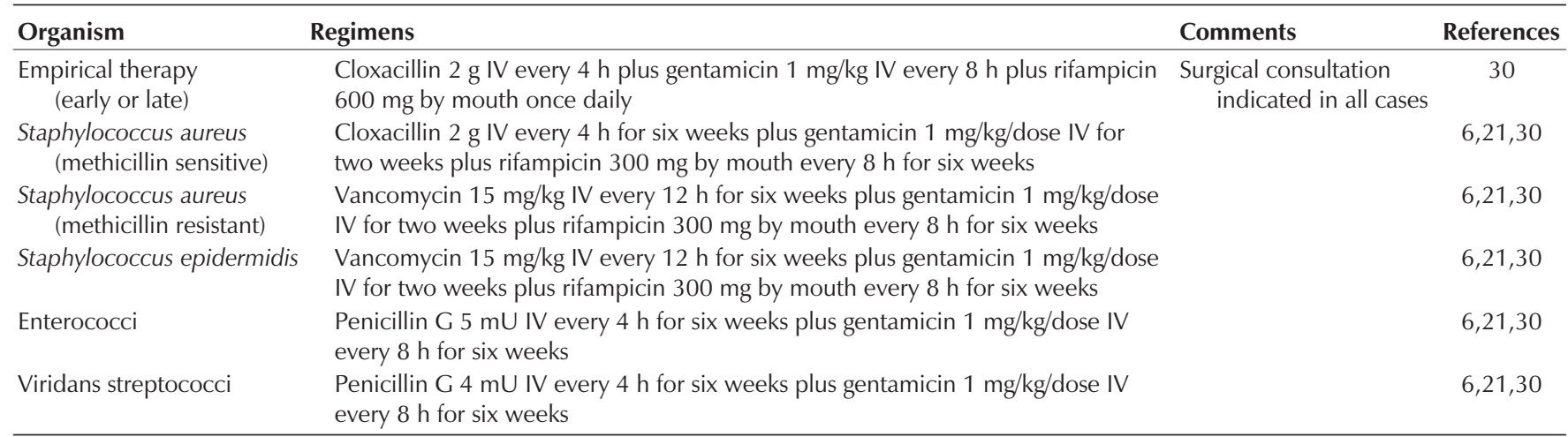

IV Intravenous

hould be reserved for patients with a penicillin allergy or for the treatment of methicillin-resistant $S$ aureus and methicillinresistant coagulase-negative staphylococci $(25,26)$.

HACEK organisms: The HACEK organisms (Haemophilus parainfluenzae, Haemophilus aphrophilus, Actinobacillus actinomycetemcomitans, Cardiobacterium hominis, Eikenella corrodens and Kingella kingae) are slow-growing, fastidious, Gram-negative bacilli that typically produce a subacute IE.
Most HACEK isolates produce beta-lactamases and are resistant to penicillin or ampicillin. Third-generation cephalosporins have excellent activity against this group, and a four-week course of ceftriaxone is the treatment of choice (21). A fourweek course of ampicillin and gentamicin may be used if the isolate is a nonbeta-lactamase producer (21).

PVE: $S$ aureus and $S$ epidermidis are commonly implicated in both early and late PVE. Viridans streptococci and enterococci 
TABLE 5 COPYRIGHT PULSUS GROUP INC. " DO NOT COPY

Recommended antibiotic regimens for the treatment of infectious endocarditis in injection drug users

\begin{tabular}{|c|c|c|c|}
\hline Organism & Regimens & Comments & References \\
\hline Empirical therapy & $\begin{array}{l}\text { Cloxacillin } 2 \mathrm{~g} \text { IV every } 4 \mathrm{~h} \text { plus gentamicin } 1 \mathrm{mg} / \mathrm{kg} \text { IV every } 8 \mathrm{~h} \\
\text { Vancomycin } 15 \mathrm{mg} / \mathrm{kg} \text { IV every } 12 \mathrm{~h} \text { plus gentamicin } 1 \mathrm{mg} / \mathrm{kg} \text { IV every } 8 \mathrm{~h}\end{array}$ & $\begin{array}{l}\text { Regimen for patients } \\
\text { with penicillin allergy }\end{array}$ & 30 \\
\hline $\begin{array}{l}\text { Staphylococcus aureus } \\
\text { (methicillin-sensitive) }\end{array}$ & $\begin{array}{l}\text { Cloxacillin } 2 \text { g IV every } 4 \mathrm{~h} \text { for four weeks plus gentamicin } 1 \mathrm{mg} / \mathrm{kg} / \text { dose for five days } \\
\text { Cloxacillin } 2 \mathrm{~g} \text { IV every } 4 \mathrm{~h} \text { for two weeks plus gentamicin } 1 \mathrm{mg} / \mathrm{kg} / \mathrm{dose} \text { for two weeks } \\
\text { Ciprofloxacin } 750 \mathrm{mg} \text { by mouth bid for four weeks plus rifampicin } 600 \mathrm{mg} \text { by mouth } \\
\text { bid for four weeks }\end{array}$ & & 27,28 \\
\hline $\begin{array}{l}\text { Staphylococcus aureus } \\
\quad \text { (methicillin-resistant) }\end{array}$ & $\begin{array}{l}\text { Vancomycin } 1 \mathrm{~g} \text { IV every } 12 \mathrm{~h} \text { for four weeks plus gentamicin } 2 \mathrm{mg} / \mathrm{kg} / \text { dose every } 8 \mathrm{~h} \\
\text { for five days }\end{array}$ & & \\
\hline
\end{tabular}

IV Intravenous

TABLE 6

Treatment of infectious endocarditis in penicillin-allergic patients

\begin{tabular}{|c|c|c|c|}
\hline Organism & Regimens & Comments & References \\
\hline Empirical therapy & Vancomycin 15 mg/kg IV every $12 \mathrm{~h}$ plus gentamicin 1 mg/kg IV every $8 \mathrm{~h}$ & & \\
\hline \multicolumn{4}{|l|}{ Native valve endocarditis } \\
\hline $\begin{array}{l}\text { Staphylococcus aureus } \\
\text { (methicillin sensitive } \\
\text { or methicillin resistant) }\end{array}$ & $\begin{array}{l}\text { Vancomycin } 1 \mathrm{~g} \text { IV every } 12 \mathrm{~h} \text { for six weeks plus gentamicin } 2 \mathrm{mg} / \mathrm{kg} / \mathrm{dose} \\
\text { every } 8 \mathrm{~h} \text { for five days }\end{array}$ & & $1,6,21$ \\
\hline Viridans streptococci & Ceftriaxone 2 g IV once daily for four weeks & Ceftriaxone-based & $1,6,21,22$ \\
\hline Nutrient-deficient streptococci & $\begin{array}{l}\text { Ceftriaxone } 2 \mathrm{~g} \text { IV once daily plus gentamicin } 1 \mathrm{mg} / \mathrm{kg} / \text { dose IV every } 8 \mathrm{~h} \\
\text { for two weeks } \\
\text { Vancomycin } 15 \mathrm{mg} / \mathrm{kg} \text { IV every } 12 \mathrm{~h} \text { for four weeks }\end{array}$ & $\begin{array}{l}\text { regimens may be } \\
\text { used in penicillin- } \\
\text { allergic patients, }\end{array}$ & \\
\hline Enterococci & $\begin{array}{l}\text { Vancomycin } 15 \mathrm{mg} / \mathrm{kg} \text { IV every } 12 \mathrm{~h} \text { for six weeks plus gentamicin } \\
1 \mathrm{mg} / \mathrm{kg} / \text { dose IV every } 8 \mathrm{~h} \text { for six weeks }\end{array}$ & $\begin{array}{l}\text { because the risk } \\
\text { of cross-reactivity } \\
\text { is minimal }\end{array}$ & $1,6,21$ \\
\hline \multicolumn{4}{|l|}{ Prosthetic valve endocarditis } \\
\hline Empirical therapy & $\begin{array}{l}\text { Vancomycin } 15 \mathrm{mg} / \mathrm{kg} \text { IV every } 12 \mathrm{~h} \text { plus gentamicin } 1 \mathrm{mg} / \mathrm{kg} \text { IV every } 8 \mathrm{~h} \\
\text { plus rifampicin } 600 \mathrm{mg} \text { by mouth once daily }\end{array}$ & & 30 \\
\hline $\begin{array}{l}\text { Staphylococcus aureus } \\
\text { (methicillin-sensitive } \\
\text { or methicillin-resistant) }\end{array}$ & $\begin{array}{l}\text { Vancomycin } 15 \mathrm{mg} / \mathrm{kg} \text { IV every } 12 \mathrm{~h} \text { for six weeks plus gentamicin } \\
1 \mathrm{mg} / \mathrm{kg} / \text { dose IV for two weeks plus rifampicin } 300 \mathrm{mg} \text { by mouth every } 8 \mathrm{~h} \\
\text { for six weeks }\end{array}$ & & 6 \\
\hline Staphylococcus epidermidis & & & \\
\hline \multicolumn{4}{|l|}{ Endocarditis in injection drug users } \\
\hline Empirical therapy & Vancomycin 15 mg/kg IV every 12 h plus gentamicin 1 mg/kg IV every 8 h & & 30 \\
\hline $\begin{array}{l}\text { Staphylococcus aureus } \\
\text { (methicillin sensitive } \\
\text { or methicillin resistant) }\end{array}$ & $\begin{array}{l}\text { Ciprofloxacin } 750 \mathrm{mg} \text { by mouth bid for four weeks plus rifampicin } 600 \mathrm{mg} \\
\text { by mouth bid for four weeks } \\
\text { Vancomycin } 1 \mathrm{~g} \text { IV every } 12 \mathrm{~h} \text { for four weeks plus gentamicin } \\
2 \mathrm{mg} / \mathrm{kg} / \text { dose every } 8 \mathrm{~h} \text { for five days }\end{array}$ & & 28 \\
\hline
\end{tabular}

may also produce late PVE. A combination of intravenous vancomycin, gentamicin and oral rifampicin is a good empirical regimen for PVE (21). Specific regimens are given in Table 4. All treatment courses are for six weeks unless otherwise indicated. Early surgical consultation should be obtained in all cases of PVE (14).

Endocarditis in IDUs: Staphylococcus aureus is the most common etiological organism in this situation. A two-week regimen of cloxacillin plus gentamicin is curative in most cases of uncomplicated infection, especially if a clinical and bacteriological response is seen within $96 \mathrm{~h}$ of initiating therapy (27). A longer treatment course should be given if there is evidence of complications such as hemodynamic compromise, systemic emboli or a metastatic focus of infection. A four-week oral regimen of ciprofloxacin plus rifampicin is also effective, although this regimen should not be used for treating methicillin-resistant $S$ aureus infections (28).

\section{OPAT FOR IE}

OPAT for IE is an increasingly attractive option in the current climate of cost containment. The availability of single, daily dose regimens and computerized ambulatory infusion pumps has made it possible to provide optimal home intravenous therapy for most cases of IE while minimizing the need for a prolonged hospital admission. The approach to placing a patient on home intravenous therapy is outlined in Figure 1.

The choice of the antibiotic regimen for OPAT will depend on the type of infecting organism, the method of administration (ie, with or without a programmable infusion pump) and the ability of the patient to self-administer the antibiotics. Penicillinand cloxacillin-based regimens are the most economical if the patient is able to self-administer the drugs or if it is possible to use an infusion pump. If a nursing visit is required to administer each dose, then the use of more expensive once-a-day agents such as ceftriaxone becomes more economical. 

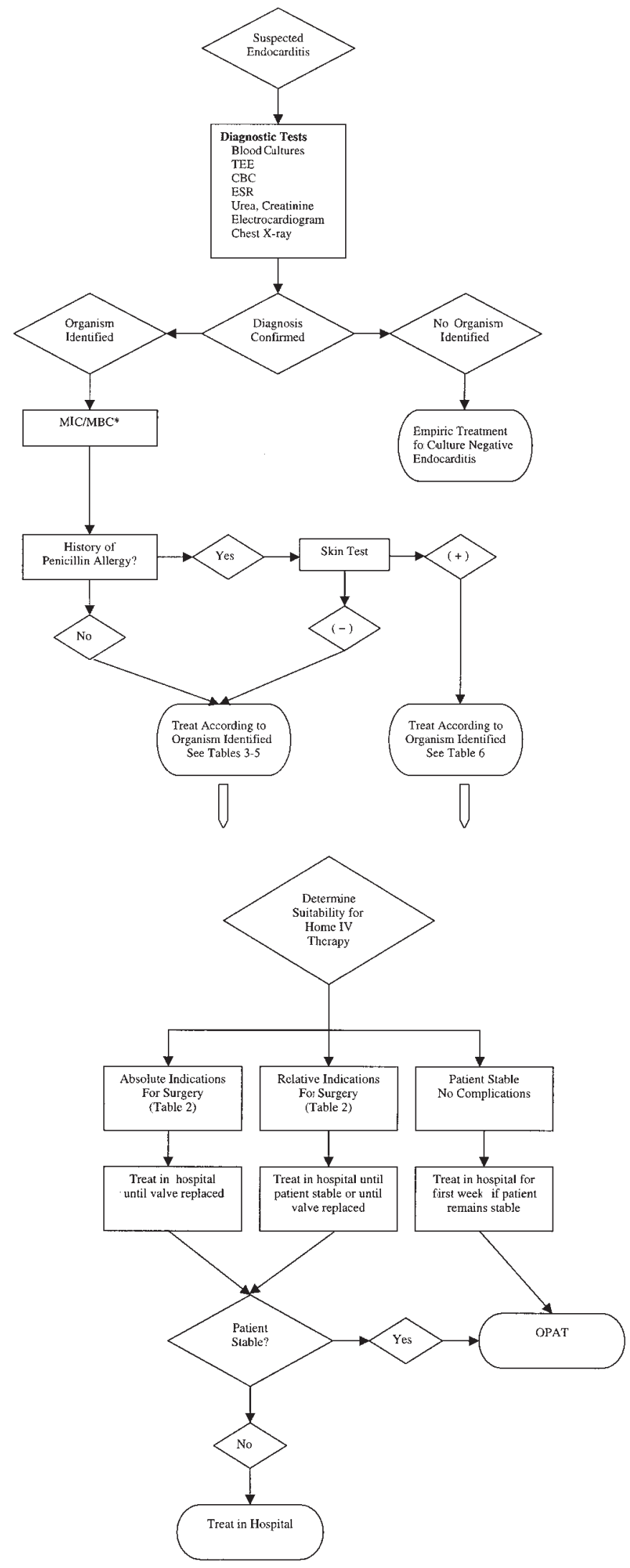

Figure 1) Approach to the diagnosis and management of infection endocarditis. + Positive result; - Negative result; CBC Complete blood cell count; ESR Erythrocyte sedimentation rate; MBC Minimum bactericidal concentration; MIC Minimum inhibitory concentration; OPAT Outpatient parental antibiotic therapy; TEE Transesophageal echocardiography 
Patients selected for home intravenous tnerapy must be medically stable and should be monitored in hospital for at least the first week of intravenous therapy. They should also meet the general eligibility criteria for home intravenous therapy. The patients and their caregivers should be familiar with the risk of embolic complications and informed that the risk of complications is the same with both inpatient and outpatient therapy. The patients should be instructed to report immediately any new symptoms that develop and should have prompt access to medical care in the event of complications.

The patient should report any new fever, systemic symptoms (eg, night sweats, malaise, weakness) or embolic complications that develop during therapy. All patients should have complete blood counts and renal function tests (urea and creatinine) performed weekly. Patients being managed with aminoglycosides should have the peak antibiotic level measured at the start of therapy, followed by weekly measurements of trough levels to minimize the risk of toxicity. The desired peak and trough levels for gentamicin are 3 to $4 \mathrm{mg} / \mathrm{L}$ and less than $1.0 \mathrm{mg} / \mathrm{L}$, respectively. Patients on oral rifampin should also have weekly

\section{REFERENCES}

1. Stamboulian D, Carbone E. Recognition, management and prophylaxis of endocarditis. Drugs

1997;54:730-44.

2. Selton-Suty C, Hoen B, Grentzinger A, et al. Clinical and bacteriological characteristics of infective endocarditis in the elderly. Heart 1997;77:260-3.

3. Chambers HF, Morris DL, Tauber MG, et al. Cocaine use and the risk for endocarditis in intravenous drug users. Ann Intern Med 1987;106:833-6.

4. Griffin MR, Wilson WR, Edwards WD. Infective endocarditis, Olmstead County, Minnesota, 1950 through 1981. JAMA 1985;254:1199-202.

5. Kay KM, Kay D. Laboratory findings including blood cultures. In: Kaye D, ed. Infective Endocarditis, 2nd edn. New York: Raven Press, 1992:117-24.

6. Bansal RC. Infective endocarditis. Med Clin North Am 1995;79:1205-40.

7. Mckinsey DS, Ratts TE, Bisno AL. Underlying cardiac lesions in adults with infective endocarditis. The changing spectrum Am J Med 1987;82:681-8.

8. Rutledge R, Kim BJ, Applebaum RE. Actuarial analysis of the risk of prosthetic valve endocarditis in 1,598 patients with mechanical and bioprosthetic valves. Arch Surg 1985;120:469-72.

9. Douglas JL, Cobbs CG. Prosthetic valve endocarditis In: Kaye D, ed. Infective Endocarditis, 2nd edn. New York: Raven Press, 1992:375-96.

10. Karchmer AW, Dismukes WE, Buckley MJ, Austen WG. Late prosthetic valve endocarditis: clinical features influencing therapy. Am J Med 1978;64:199-206.

11. Hermans PE. The clinical manifestations of infective endocarditis. Mayo Clin Proc 1982;57:15-21.

12. Sande MA, Lee BL, Mills J, Chambers HF. Endocarditis in intravenous drug users. In: Kaye D, ed. Infective Endocarditis, 2nd edn. New York: Raven Press, 1992:345-59.

13. Bush LM, Johnson CC. Clinical syndrome and diagnosis. In: Kaye D, ed. Infective Endocarditis, 2nd edn. New York: Raven Press, 1992:99-115.

14. Moon MR, Stinson EB, Miller DC. Surgical treatment of endocarditis. Prog Cardiovasc Dis 1997;40:239-64.

15. Steckelberg JM, Murphy JG, Ballard D, et al. Emboli in infective endocarditis: the prognostic value of echocardiography. Ann Intern Med 1991;114:635-40.

16. Wilson WR, Liezt Hoset DW, Piepgras DG, et al. The management
NC. DO NOT COPY

easurements of the transaminases (aspartase aminotransferase, alanine aminotransferase) and alkaline phosphatase.

There have been no prospective, controlled trials to determine whether inpatient therapy and OPAT are equivalent in terms of mortality and morbidity. Three small studies with a cumulative total of 100 patients with streptococcal IE suggest that home intravenous therapy is safe and efficacious for this indication $(22,23,29)$. Only two patients relapsed while on therapy in these reports. A fourth retrospective study reported that only four of seven patients (56\%) completed the antibiotic course because of the development of complications (30). None of these patients relapsed, but three patients did report intravenous-related complications.

In conclusion, most cases of IE can be managed safely, economically and effectively with OPAT. Most of the recommended treatment regimens can be delivered as effectively at home as in the hospital. While there are no prospective, controlled trials to document the benefits of this approach, the authors' own personal experience and the evidence from several published reports suggests that home intravenous therapy is safe and effective.

of patients with mycotic aneurysm. Curr Clin Top Infect Dis 1981;2:151-83.

17. Johnson D. The clinical syndrome. In: Kaye D, ed. Infective Endocarditis, 2nd edn. New York: Raven Press, 1992:87-100.

18. Gurpreet SK, Maniet AR. Echocardiographic findings in infective endocarditis. Curr Opin Infect Dis 1992;5:642-6.

19. Daniel WG, Mugge A, Martin RP, et al. Improvement in the diagnosis of abscesses associated with endocarditis by transesophageal echocardiography. N Engl J Med 1991;324:795-800.

20. Durack DT, Lukes AS, Bright DR. New criteria for diagnosis of endocarditis. Am J Med 1994;96:200-9.

21. Wilson WR, Karchmer AW, Dajani AS, et al. Antibiotic treatment of adults with infective endocarditis due to streptococci, enterococci, staphylococci, and HACEK microorganisms. JAMA 1995;274:1706-13.

22. Francioli P, Etienne J, Hoigne R, Thys JP, Gerber A. Treatment of streptococcal endocarditis with a single daily dose of ceftriaxone sodium for four weeks. JAMA 1992;267:264-7.

23. Stamboulian D, Bonvehi P, Arevalo C, et al. Antibiotic management of outpatients with endocarditis due to penicillin-susceptible streptococci. Rev Infect Dis 1991;13(Suppl):S160-3

24. Korzeniowski O, Sande MA. The national collaborative endocarditis study group. Combination antimicrobial therapy for Staphylococcus aureus endocarditis in patients addicted to parenteral drugs and in nonaddicts: a prospective study. Ann Intern Med 1982;97:496-503.

25. Karchmer AW. Staphylococcus aureus and vancomycin: the sequel. Ann Intern Med 1991;115:739-41.

26. Bayer AS. Infective endocarditis. Clin Infect Dis 1993;17:313-22.

27. DiNubile MJ. Short-course antibiotic therapy for right-sided endocarditis caused by Staphylococcus aureus in injection drug users. Ann Intern Med 1994;121:873-6.

28. Heldman AW, Hartert TV, Ray SC, et al. Oral antibiotic treatment of right-sided staphylococcal endocarditis in injection drug users: prospective randomized comparison with parenteral therapy. Am J Med 1996;101:68-75.

29. New PB, Swanson GF, Bulich RG, Taplin GC. Ambulatory antibiotic infusion devices: extending the spectrum of outpatient therapies. Am J Med 1991;91:455-61.

30. Colford JM Jr, Corelli RL, Ganz JW, Guglielmo BJ, Jacobs RA. Home antibiotic therapy for streptococcal endocarditis: a call for a controlled trial. Am J Med 1993;94:111-2. 


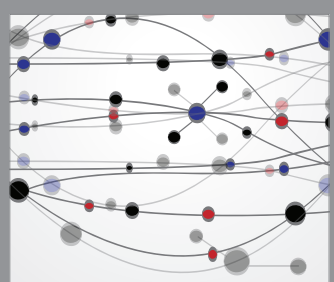

The Scientific World Journal
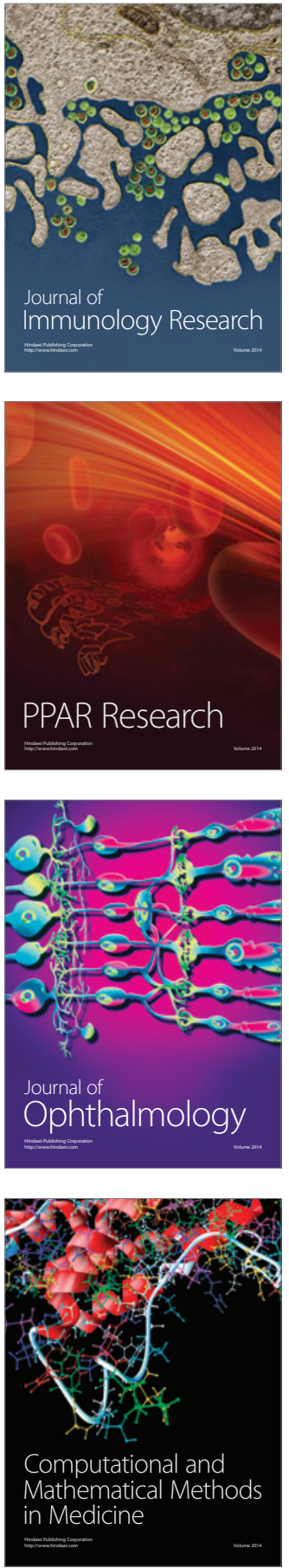

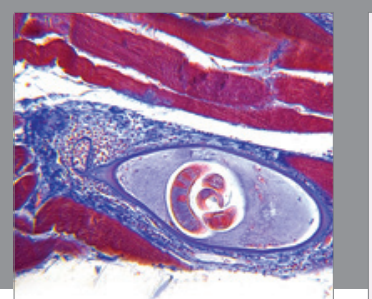

Gastroenterology Research and Practice

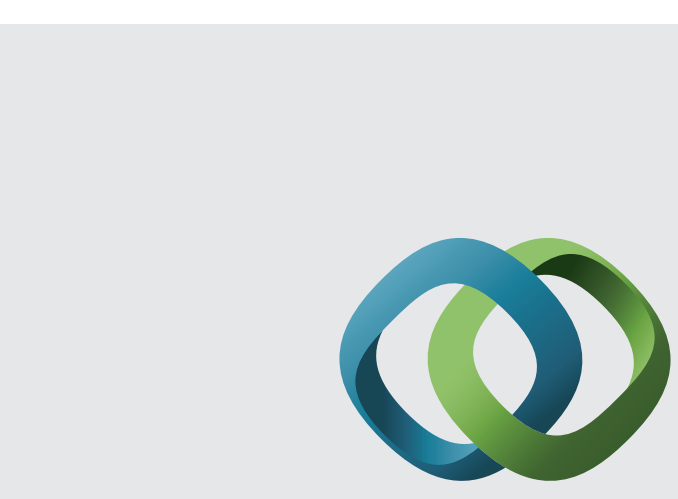

\section{Hindawi}

Submit your manuscripts at

http://www.hindawi.com
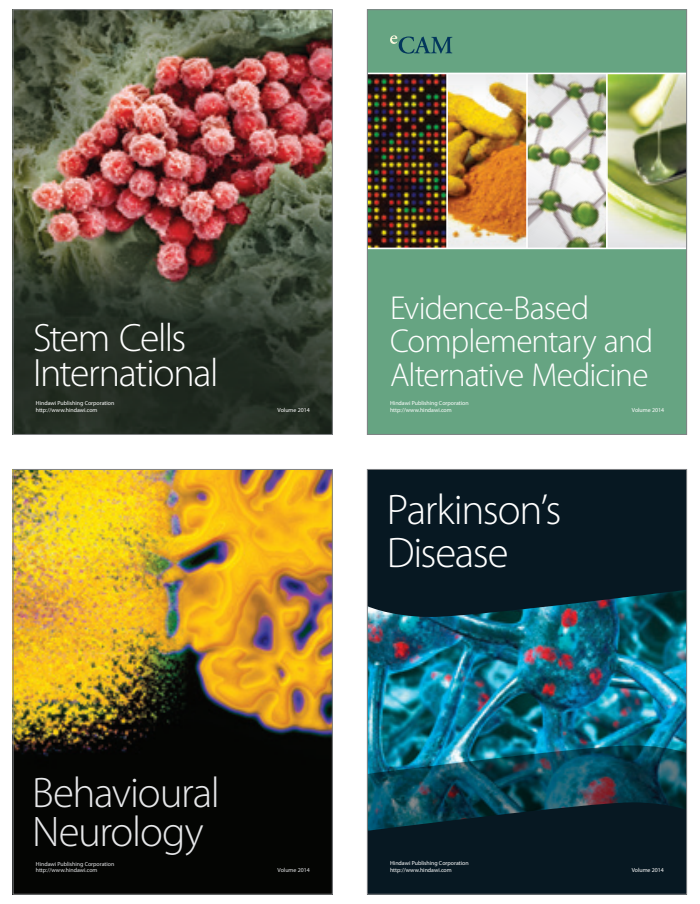
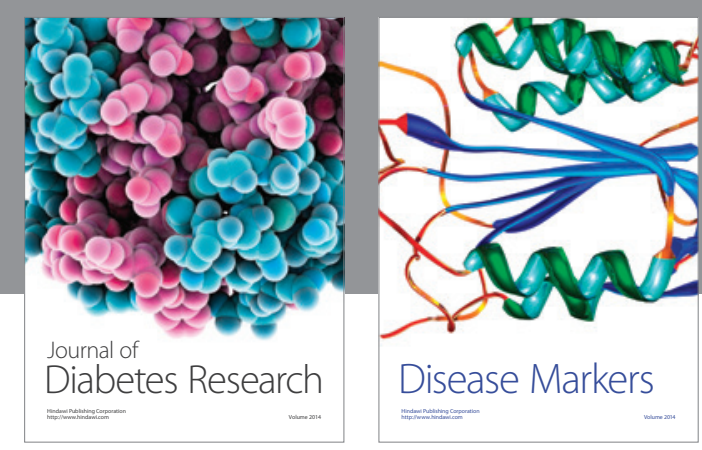

Disease Markers
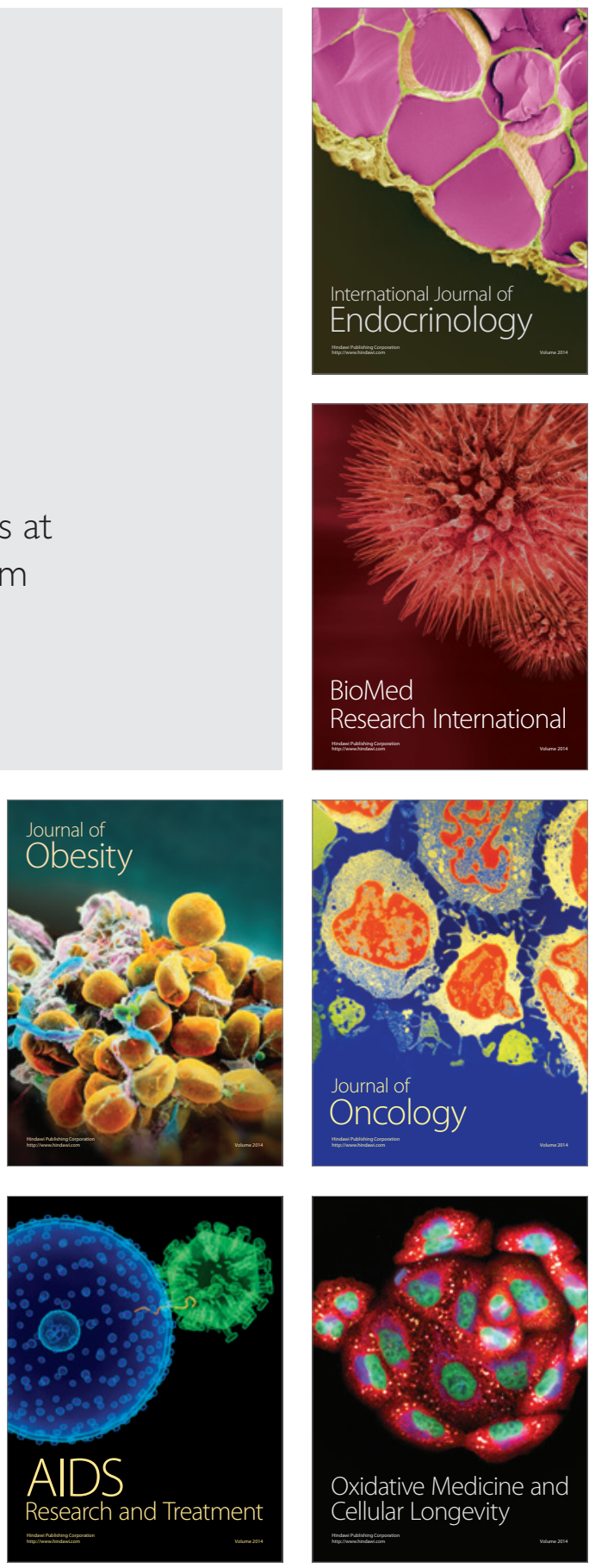